短報

\title{
森林環境譲与税を介した都市-農山村連携 一埼玉県秩父市と東京都豊島区の事例から一
}

\author{
香坂 玲*,1 • 大澤太郎 ${ }^{2} \cdot$ 内山愉太 ${ }^{1}$
}

2019 年 4 月に森林経営管理法が創設され，市町村を中心とした新たな森林管理の枠組みが設けられ，そのための費用が森林 環境税の導入に先駆けて同年度から市町村に交付される。その地方譲与税としての森林環境譲与税の自治体への配分について は, 私有林人工林率のみならず，人口も考虑されるため，都市部にも一定の配分がなされる。都市部では木材利用の促進といっ た施策が進められる傾向にあるが, 本来の制度趣旨に沿うかたちで, 都市一農山村連携を促すことも意図されている。本稿では, その萌芽的事例として, 東京都豊島区と埼玉県秩父市の事例を対象として, 連携の経緯と課題, 可能性について考察を行った。 結果，両自治体の姉妹都市としてのこれまでの経験や，秩父市における周辺自治体との広域連携を含む林政の展開が，環境䛦 与税を活用した都市一農山村連携のコンテクストとなっており，環境譲与税のさらなる活用に向けた県と市の人事交流による人 的資源の補完等の可能性も把握された。

キーワード：都市-農山村連携，森林環境税，市町村，森林環境譲与税

Ryo Kohsaka, ${ }^{*, 1}$ Taro Osawa, ${ }^{2}$ Yuta Uchiyama ${ }^{1}$ (2020) Forest Environment Transfer Tax and Urban-rural Collaboration: Case of Chichibu City and Toshima District in Japan. J Jpn For Soc 102: 127-132 The year 2019 marked the first year of introducing the national forest environment transfer tax. The forest environment transfer tax scheme is mainly for the forest management in municipalities. Yet the forest areas in certain urban areas are limited and there is a room for urban-rural collaboration. In concrete terms, urban municipalities can receive relatively large revenue from the tax, because total population of municipalities is considered as one of the indicators to compute the amount of transferred tax for the municipalities. The urban municipalities can use the tax to facilitate the use of wood products, such as construction materials, and to conduct forest management in rural municipalities by implementing urban-rural collaboration. As a case of the urban-rural collaboration, collaboration between Toshima District and Chichibu City was analyzed and their process of collaboration and status of sharing human resources in Chichibu City and Saitama Prefecture were identified. Toshima District and Chichibu City have longterm experience of collaboration as sister municipalities. Chichibu City is conducting regional collaboration with surrounding municipalities on forest managements. These are the contexts of facilitating Toshima and Chichibu's urban-rural collaboration.

Key words: urban-rural collaboration, forest environment tax, municipalities, forest environment transfer tax

\section{I. は じめ に}

\section{1. 森林環境譲与税をめぐり市町村の林政が抱える課題 一なぜ連携が困難なのか一}

森林経営管理法が 2019 年 4 月に創設され，市町村を中 心とした新たな森林管理の枠組みが設けられた。同時にそ のための費用を森林環境税の導入に先駆けて同年度から市 町村に交付することとなった。2019年度より，基礎自治 体である市町村に対して, 森林環境譲与税（以下，環境譲 与税)の交付が開始されている。譲与基準は次の 3 変数（括 弧内は比率）に基づいている：各自治体の私有林人工林面 積 $(5 / 10)$, 林業就業者数 $(2 / 10)$, 総人口 $(3 / 10)$ 。各自治 体への配分額は私有林人工林面積等のみならず人口も考慮 されるため, 都市部の自治体にも一定の金額が配分される。 もともと，その源流の異なる二つの政策である森林経営管 理法と森林環境税（並びに環境譲与税）であったが，税制 大綱をはじめ, 都道府県の説明では緩やかに対をなすよう な形での説明が定着しつつある。

現在の予定では, 2024 年の森林環境税導入による徵収 が始まり，その使途が公開される。都市とそれ以外の地域 を問わず納税者の納得を得るためにも，制度趣旨に合致し
た使途の模索が続いている。森林経営管理制度および環境 譲与税の活用をめぐる課題は, 市町村ごとにその局面や特 徵が大きく異なる。特に, 森林整備と林業振興については, 各市町村に扔ける取り組みに加えて, 市町村の広域連携が 欠かせない。しかしながら, 広域連携を実践することは容 易ではなく, 課題が山積している。市町村ごとの課題や, 広域連携の課題の具体的な背景について以下に述べる。

第一に都市部は, 林野が多く存在するエリアとは異なる 課題を抱えている。私有林人工林が比較的多く存在する農 山村の場合には, 森林所有者の意向調查, その前提になる 所有者探索，間伐，集積計画などに向けた使途が想定され る。しかし都市部ではそもそも環境譲与税の制度が課題と して指摘した管理の行き届いていない私有林人工林が存在 しない場合や，限定的であるケースが多い。日本の市町村 の多くは, 都市部と農山村部の比率はそれぞれ異なるもの の, その両方を含んでいる。市町村合併により広域化した 市町村等では特に, 都市部と農山村部の両方の課題に同時 に対応する必要がある。このような状況下で, 都市部の比 率の高い市町村や森林が少ない市町村の税の主な使途とし ては,「木材利用の推進」を揭げる市町村が多い。都市部 での使途として初期の 2019 年段階で目立つのが, 公立学

*連絡先著者 (Corresponding author) E-mail: kohsaka@hotmail.com

1 名古屋大学大学院環境学研究科 T464-8601 愛知県名古屋市千種区不老町 D2-1 (Graduate School of Environmental Studies, Nagoya University, Furo-cho D2-1, Chikusa-ku, Nagoya, Aichi 464-8601, Japan)

2 秩父市役所環境部⿳亠丷厂彡368-8686 埼玉県秩父市熊木町 8-15（Chichibu City, Division of Environment, Kumaki-cho 8-15, Chichibu, Saitama 3688686, Japan)

(2019 年 9 月 25 日受付； 2020 年 1 月 26 日受理) 
校の校舎, 病院, 公共建築物に係る「木材利用」である。 横浜市なども，市の単位で独自に超過課税を導入している 特殊性があり，広域の森林を有するものの，大規模な人口 を抱える政令市として，環境譲与税を市内の公共建築物の 木質化に振り分ける予定である。

第二に市町村ごとに讓与の額や配分される要因が大きく 異なってくる実情がある。上述の変数を基に配分額が算出 された結果，配分額の大きい上位の市町村には，政令市等 の人口規模の大きい市町村と, 人口は少ないが，私有林人 工林面積の大きい市町村が混在する状況となっている（吉 弘 2019)。人口が考慮されることによって, 森林環境の整 備のための税が，都市部の比率の高い市町村にも配分され る。そのことは，本稿でも主眼となる，都市部に配分され る予算等を活用した農山村の森林整備, 林業振興, 都市部 での木材利用の促進等にもつながることが期待されてい る。環境譲与税並びに地方譲与税の詳細については, 先行 研究（香坂・内山 2019）において解説されている。

第三に, 都市一農山村に限らず, 市町村の境界線を越えた 連携が難しい実情がある。市町村に交付される譲与税は, 首長の意向, 市町村の行政体の説明責任が意識された結果, 「その市町村のエリア内で使うこと」に意識が向いている ケースが多い。またその制度の「譲与」という性質上，国 や都道府県が広域的な連携については, 直接的な誘導や指 導はせず，後方支援に留まっていることも要因となってい る。例えば, 広域の森林整備等について, 事務局機能を複 数の市町村について集約して設定することについても一案 として議論されるが,話し合いが進まない状況が散見される。

最後に, 都市, 農山村を問わず, 大多数の市町村に扔いて, 森林の管理や政策に関わるノウハウや人的資源が限られて いることが, 環境譲与税の活用をめぐる課題の主要因となっ ていることについて述べる。既存研究 (今井 2018 ; 飛 田 2019 ; 香坂・内山 2019）で指摘されているように，現 実の市町村の林政の現場では，税収の多萓よりも「限られ た人的資源とノウハウ」がボトルネックとなる可能性が高 い。そもそも，人員を増やすほどの交付額ではないケース も多い（注 1)。市町村によっては大型の税収が見込まれる が，実態としては行政・現場のマンパワーや担い手不足の 問題が深刻化している。そのため「そもそも連携を考える 余裕がない」というケースも多いのも実情である。

\section{2. 都市-農山村の連携の可能性}

以上の課題, 状況を市町村が抱えている結果として, 本 来であれば環境譲与税を活用することによって都市部と農 山村の連携が大きな効果を発揮しうる余地があり, 吸収源 対策としても一定の役割を果たし得ることや, 納税者の納 得感を醸成できる可能性もあるにも関わらず，現状では環 境譲与税を活用した都市一農山村連携の動きは全国的に限 られている。

都市一農山村連携は, 環境譲与税の文脈に限らず, 多様 な枠組みにおいて実施されてきた。例えば，流域圈での連 携や市町村の広域連携, 都市農山村交流の枠組及等での蓄 積がある（天田ら 1999 ; 齋藤 2014 ; 小山ら 2017)。特に, 市町村連携としての都市一農山村連携について，林政の文
脈で具体的な事例を基に直接的に論じている既存研究は限 定的である。流域圈での連携では, 個々の市町村間の関倸 性に注目するよりは, 多数の市町村が含まれる範囲で, 労 働力や資本の分布がマクロな観点から分析されてきた（梶 本ら 2006)。都市と農村の交流に関する研究の言説の変遷 を分析した研究では, 1970 年代以降, 農業経済分野でのマ クロな観点からの就業機会の分析から, よりミクロなサー ビス財等を扱う方向へと変化していることや，当初は農村 が都市側の事情で翻弄されるような状況がみられたが, 都 市と農村が協働するかたちへと変化していることが指摘さ れている (小山ら 2017)。市町村の広域連携では, インフ ラ管理が喫緊の課題として捉えられる傾向があり（大貝・ 谷 2010), 広域市町村圈や地方中枢拠点都市圈等の全国的 に構想されてきた連携の枠組みでは, 資本のための合理化, 効率化が重視された結果, 顕著な正の効果を期待することが 難しい状況も指摘されてきた（天田ら 1999 ; 青山 2015）。 グリーンツーリズムを含む都市農山村交流の議論では, 市町 村内部の個別の事業や取組みが注目されることが多い（齋 藤 2014)。都市部の比率の高い自治体と主に農山村部によっ て占められている自治体が，自治体間協定等を基に協働する 例は, 林政分野において都市一農山村連携の方法論としては 伝統的に議論されてきた。ただし, 実践としては新しい取組 みであると同時に, 都市農山村交流の歷史における最新の動 向としての, 市町村間の双方向的な協働事例としても位置付 けられる。

以上の環境譲与税の特性と都市一農山村連携の動向を踏 まえて, 本稿では, 全国に先駆けて都市部の東京都豊島区 と主に農山村部によって構成される埼玉県秩父市が連携を 実現した経緯を提示する。特に, 連携事業の内容に加えて, そのコンテクストに関して秩父市の広域連携や体制整備に ついても概要を示す。先行する事例を短報という形で紹介 することにより, 連携を検討する自治体関係者, 研究者の 今後の分析の参考に供することを意眓している。

\section{II. 分析対象・分析方法}

\section{1. 対象地域}

埼玉県秩父市の林野面積は 50,064 ha, 林野率 87\% で, 国有林は 11,467 ha, 民有林は 38,597 ha であり, 東京都豊 島区には林野は無い（農林水産省 2016）。秩父市の私有林 面積および市有林面積は，それぞれ22,362 ha，3,073 ha と なって扮り（農林水産省 2016）, 人工林面積は 16,679 ha（秩 父市2018), 私有林人工林面積は 10,706 ha（林野 庁 2017）となっている。秩父市の林家は 1,153 戸で, 林 業経営体数は 44 , 組織経営体が 10 , 家族経営体が 34 となっ ている（農林水産省 2016）。市を含んだ秩父地域では, 過 疎化, 担い手不足, 森林整備の遅れが問題となっている（日 刊木材新聞 2019 年 7 月 18 日)。比較的高い林野率および 民有林率を有する秩父市では, 先進的な林政を展開してい る。例えば同市は, 都市一農山村連携の他にも, 2019 年 6 月に全国に先駆けて市内 2 カ所の私有林について「経営管 理権集積計画」の公告を行っており, 森林経営管理法の観 点からも先進的な市として注目を集めている。秩父市の特 
徵的な施策としては，環境譲与税の開始に合わせて，近隣 4 町（横瀬町，皆野町，長清町，小鹿野町）と連携して林 業を再興する施策も行っている。

地域内連携の最近の動きとして，2012 年 5 月に設立さ れた秩父地域森林林業活性化協議会（以下，協議会）にお ける，2019年 4 月の集約化推進室の設置（日刊木材新聞 2019 年 4 月 6 日), 集約化推進員 2 名の雇用がある。秩父 市と近隣 4 町の秩父地域の森林面積は, 75,148 ha で, 国 有林 $15 \%$ ，民有林 $85 \%$ ，58\%が私有林となっている（農 林水産省 2016)。集約化推進員の現在の主な業務は，森林 所有者の意向調査の実施で，46エリアに地域を分け， 1 年 5 エリアずつ, 9 年で終了する予定である。そのペースは, 林野庁の示す 15 年という目安よりかなり早いと言える。 協議会にはこれまで 7 年間の活動実績があり，1市 4 町と 森林組合, 地域の民間業者等が参加している（図-1）。推 進員は，森林組合・林業事業体からの出向であり，環境譲 与税の一部が給与として協議会に拠出されている。この協 議会を活用した市町連携には，秩父市長による指示も関 わっている。担当部署のない 4 町との連携を秩父市が行う 意図は，地域の一体的な森林整備を行うという点にある。 秩父市が経営管理権集積計画作成・公告を全国で最も早く 行ったのは森林整備の発注までのモデルを広域地域に波及 させるとの意図が背景にある。市町村における全体的な傾 向として，首長等を如何に林政に目を向けさせるかが課題 となっている状況下で，秩父市は首長が林政に積極的な姿 勢を示しつつ, 周辺地域との連携も進め, 以下結果の章で 述べる通り組織体制の強化がなされている点でも特徴的な 市といえる。

\section{2. 分析対象の事業}

今回の対象事業は, 農山村地域である秩父市内の, 管理 が十分になされてこなかった市有林について，都市部であ る豊島区の環境譲与税を活用して温暖化原因物質の吸収源 対策として整備するという都市-農山村連携の事業である。 正式名称は「自治体間連携によるカーボン・オフセット事 業」である（豊島区 2019）。港区による「協定木材」（間 伐材を始めとした国産材の活用促進に関する協定）におけ る福島県いわき市，埼玉県飯能市など，農山村と都市部の カーボン・オフセットの取り組みのモデルは他にも存在す

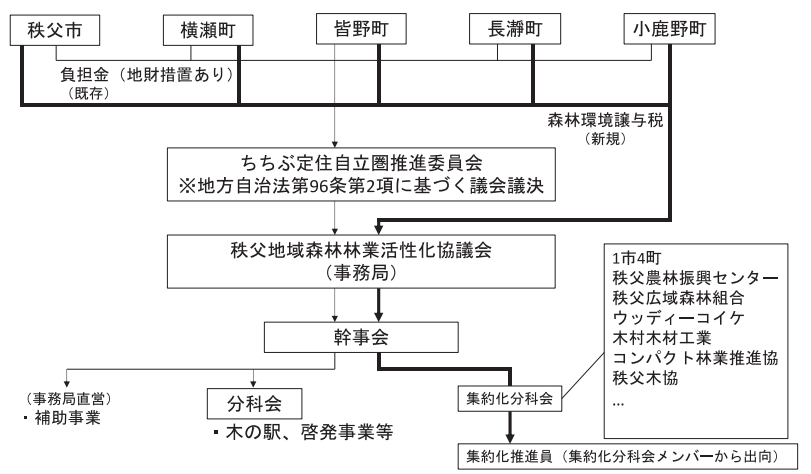

眓-1. 秩父地域森林林業活性化協議会と自治体連携の構造

既存のちちぶ定住自立圈推進委員会の連携体制を基礎として, 森林環境譫 与税の活用に関して秩父地域森林林業活性化協議会において検討される枠 組みとなっている。
るが，環境譲与税を原資とした取り組みは全国でも初めて である。

具体的には，豊島区と秩父市の森林整備の実施に関する 協定書が 2019 年 7 月に締結されている。その中身は, 秩 父市内の市有林の一部（1.89 ha）を「としまの森」（秩父 市田村字長沢 171 172-2 172-3） として設定し, 豊島区民 も参画する形で，整備と普及啓発を含む交流事業を実施す るという内容である。同じエリア内の市有林の 2 割程度が 今回の対象であり，事業対象地は今後拡大する余地も残っ ている。55 年生の雑木林 (コナラ, ヤマザクラ等) の択伐・ 萌芽更新による若返りを主な活動とする。今回, 合意に至っ た協定期間は，協定が発表された 2019 年 7 月 10 日から 2024 年 3 月 31 日の 5 力年度間となっている。担当課は, 秩父市環境部森づくり課と, 豊島区環境清掃部環境政策課 である。

背景には，秩父市には豊島区との 1983 年からの姉妹都 市としての交流の蓄積があることや, 近隣の 4 町と連携し た協議会など, 秩父市が独自に林業に注力し, 既存の組織 的な枠組みが存在してきたという要因も大きい。環境譲与 税が導入されたことも今回の秩父市と豊島区の協定の主要 背景であるが, 秩父市が豊島区や近隣の町とこれまで連携 してきた長期的な取り組みの蓄積も影響している。

予算源は都市部の東京都豊島区へ譲与される環境譲与税 等が活用されており, 事業費は 5,204 千円となっている（注 2)。まず豊島区の環境譲与税を森林整備負担金として秩父 市の歳入とする。秩父市は, 同負担金を原資とした森林整 備委託金をもとに，意欲と能力があるとされる林業事業体 に森林整備やイベントの指導の委託をし, 除伐や自然体験 等の豊島区民も対象とした交流事業を実施する。CO2 吸 収量については，第三者認証等のクレジットではなく，よ り簡便な「埼玉県森林 CO2 吸収量認証制度」を活用し, 豊島区内で発生する $\mathrm{CO} 2$ 排出量と相殺するスキームであ る。計画では, 初年度で 4.5 トン, 5 年間で 22.5 トンを想 定している。

秩父市としては, 豊島区の要望等を受け, バス等の公共 交通機関で訪ねられる手近な場所の森林を貸与すること や, 森林整備, イベントの指導の受託をする。（他にも施 設として，仮設トイレ，フェンスの設置等が検討されてい る)。秩父市側も，としまの森の受け入れ費用として，秩 父市の環境䜇与税による財源のうち 160 千円（旅費, 消耗 品費）の支出を予定している。

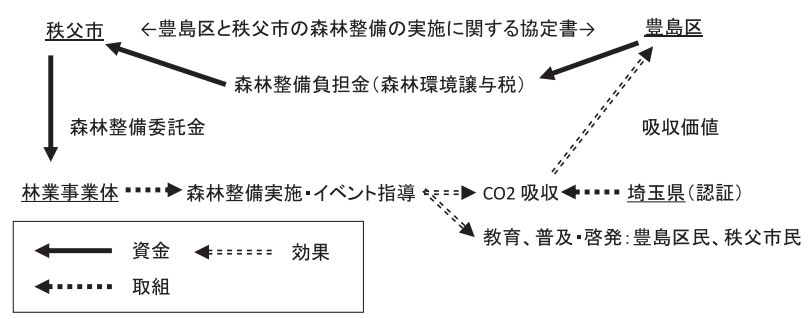

図-2. 秩父市と豊島区の連携事業のスキーム

豊島区・秩父市提供資料を基に筆者作成。カーボン・オフセット事業として, 豊島区の森林環境譲与税が, 森林整備負担金というかたちで, 秩父市で活 用されるスキームとなっている。 


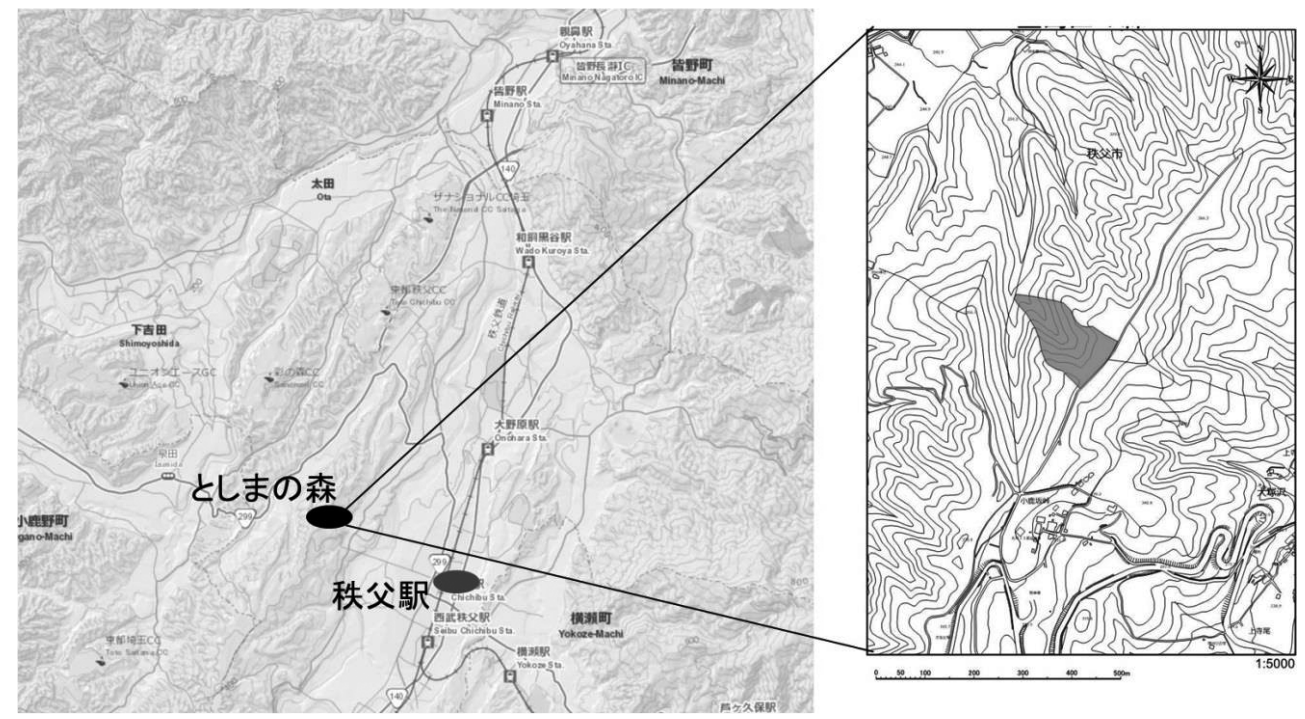

図-3. 秩父市と豊島区の連携事業の対象地「としまの森」の立地

としまの森へのアクセスは，豊島区民のアクセス性も考虑され，公共交通でアクセス可能である。



図-4. 秩父市と豊島区の連携事業の対象地「としまの森」の外 観（55 年生のコナラを中心とする雑木林）

としまの森は，55 年生のコナラを中心とする雑木林であり，今後対象地が 拡大される予定である。

\section{3. 分析方法}

調查方法として，豊島区と秩父市の担当者への対面の聞 き取りと秩父市における現地調査を実施した。聞き取りで は双方に以下の項目を質問した：１＼cjkstart連携の経緯（なぜ農山 村-都市である秩父市-豊島区の連携が可能となったのか), (2)組織の運営体制の変化, (3)課題。

\section{III. 調査分析結果}

\section{1. 結果}

以下では，上記三つの質問項目について聞き取り調査を 行った結果を整理する。

第一に，連携の経緯（なぜ農山村-都市である秩父市-豊 島区の連携が可能となったのか）について述べる。今回の 協定は，姉妹都市として 36 年間交流を行ってきた秩父市 と豊島区の信頼関係が基礎となっている。協定自体は，秩 父市からの働きかけで 2018 年 7 月より調整が開始された。 秩父市の働きかけの背景には，前述の通り林業に関する施 策展開に積極的な姿勢を有する秩父市長の指示があった。 具体的には, 都市一農山村連携ともなる, 都市部の環境譲
与税の一部を活用する施策を実施することについて，同市 長は市の関連部署に指示を行っていた。市の担当者は都市一 農山村連携を発展させ, 将来的には経営管理権を取得した 私有林の整備までを連携事業の枠組みにおいて実施したい と考えている。

秩父市の担当者を対象としたインタビュー結果と，豊島 区の担当者へのインタビューの結果を比較すると, 秩父市 の担当者は連携事業を, より広域での森林整備にまで発展 し得る事業であるとより強く意識していることが，広域化 への言及頻度から伺われる。他方で, 豊島区の担当者は, 本連携事業が環境に加えて文化，教育の側面も含む点をよ り強く意識していた。具体的には, 本事業によるカーボン・ オフセットの総量自体の, 豊島区の炭素排出量における割 合は低いため, 豊島区の担当者は, 環境学習や都市一農山 村交流のインパクトの方が現時点では相対的に大きいと捉 えていると推察される。豊島区の担当者も本連携事業を発 展させ，実施対象地域を拡大させることについて前向きの 姿勢を有しているが, 現時点の初期的段階においては, 文 化や教育といった側面が，カーボン・オフセットと同等か それ以上に意識された事業となっている。実際，としまの 森の場所の選択においては, 豊島区民の物理的なアクセス 可能性が考慮され, 公共交通によって訪問することが可能 な場所となっている。

本連携事業において，秩父市と豊島区のそれぞれが強調 したいと考えている点, 重視している点は類似している部 分と差異がみられる部分が存在することが推察された。た だし，視点に差異が生じていても，互いにメリットを享受 可能な事業を推進しようとする点については担当者レベル においても共通認識が持たれている。これまでの豊島区と 秩父市の長期的な交流や，秩父市の周辺自治体との連携の 経験も基礎としながら, 自治体間で円滑な調整が可能で あったこと, 特に秩父市においては同市の林政のこれまで の蓄積と市長がリーダーシップをとってきた点が, 今回の 都市一農山村連携としての協定事業を成立させた主要因と 
して考えられる。

第二に, 組織の運営体制の変化については, 秩父市は森 林担当部局における人員配置を強化してきた。具体的には, 秩父市環境部森づくり課では, 2017 年度から 2019 年度に かけて，非常勤等を含めた人員の補強がなされている。同 森づくり課は, 2019 年 4 月時点で課長, 技監 1 名：(埼玉 県から出向), 事務職 2 名, 専門職 2 名の常勤職員 6 名と, 非常勤職員の地域抢こし協力隊 2 名, 林政アドバイザー 1 名の合計 9 名の体制である（表-1）。

2018 年度からは, 県 OB の林政アドバイザー1名, 地域 おこし協力隊員 1 名を雇用し， 2019 年度からは，大学で 林学を学んだ林業職 2 名を主事として環境譲与税の導入に 合わせて雇用している。2019年度には地域おこし協力隊 員をさらに 1 名雇用した。環境譲与税や森林経営計画等に 関する林野庁などからの書類，マニュアル，手引きを読み 込むのは, 市町村プロパーの事務を専門とする職員では難 しい側面もあるとの指摘が，秩父市の担当者インタビュー でなされたが，秩父市の森づくり課では専門性の高い内容 を県職員（出向職員）がサポートする体制となっている。 環境譲与税の制度活用において, 県の支援と自治体間の情 報の交流が必要とされる。その制度の担当者が県から出向 した職員であったことは, 制度活用の推進と関連性がある 点である。

今後の施策に対応する人材については, 県から出向した 職員が当座の中心となっている。長期的には並行して複数 の自治体，例えば，近隣の 4 町で林政アドバイザー1名を 雇う計画も検討されている。尚, 地域おこし協力隊の取組 みは, 小規模森林所有者と同程度の規模の取組みになって いくと秩父市の担当者は見込んでいる。つまり，通常の森 林組合事業では対応しない小規模伐採の引き受け手の育成 の試みとなっている。そのために, 地域おこし協力隊員は, 最初の 3 年間は秩父市有林等で研修を受けるかたちの計画 となっている。地域おこし協力隊が上記のような小規模伐 採を含む林業施業の担い手となるには，さらに $2 \sim 3$ 年の 研修期間が必要であるとの見通しがインタビュー時に説明 された。

第三に課題については, 秩父市においては組織体制の強

表-1. 秩父市における担当職員の配置状況

\begin{tabular}{|c|c|c|c|c|}
\hline & \multicolumn{2}{|r|}{ 常勤職員 } & \multicolumn{2}{|r|}{ 非常勤職員 } \\
\hline & 人数 & 職務 & 人数 & 職務 \\
\hline \multirow{3}{*}{2017 年度 } & 1 & 課長 & & \\
\hline & 1 & 技監 & & \\
\hline & 3 & 主任（事務） & & \\
\hline \multirow[t]{2}{*}{ 計 } & 5 & & 0 & \\
\hline & 1 & 課長 & 1 & 林政アドバイザー \\
\hline \multirow[t]{2}{*}{2018 年度 } & 1 & 技監 & 1 & 地域おこし協力隊 \\
\hline & 3 & 主任（事務） & & \\
\hline \multirow[t]{2}{*}{ 計 } & 5 & & 2 & \\
\hline & 1 & 課長 & 1 & 林政アドバイザー \\
\hline \multirow{3}{*}{2019 年度 } & 1 & 技監 & 2 & 地域抗こし協力隊 \\
\hline & 2 & 主任（事務） & & \\
\hline & 2 & 主事（専門職） & & \\
\hline 計 & 6 & & 3 & \\
\hline
\end{tabular}

化が進められており, 多くの市町村において課題となって いる人的資源の不足に対応しょうとする姿勢がみられる。 そのため, 実際に森林整備を担う側の基礎自治体としての 秩父市の人的資源をめぐる問題は比較的深刻でないように もみえる。ただし, 実際には, 秩父市単独で人的資源を持 続的に確保することは困難な課題であり, 近隣 4 町や県と の連携に㧈いても費用負担の配分等については，抜本的な 解決策が見出されていない状況にあり, 人的資源を秩父市 のみならず，実際の森林整備の単位となる秩父地域におい て確保していくための解決策は模索されている状況にある。

県との人事交流は人材不足の問題に起因する専門知識の 伝達や普及・指導の問題への対応としては有効であるが, 長期的な視点から，人材を確保していく必要がある。市町 村連携において, 費用負担の問題があったとしても, 連携 する市町村間で予算を拠出して, 体制を補強するような方 向性は, 今後の少子高龄化の状況下に扔いて期待される一 つの方向性である。そのような連携を遂行するには, 市町 村を超えた連携に対する市民や行政の理解，意識を向上さ せる必要があると考えられる。

秩父市と豊島区の間で，連携事業に対する視点に差異が みられる部分が存在することは, 規模や立地, 産業等の特 性が大きく異なる市町村であることから，当然予想される ことである。現時点で, 視点の差異を起因とした軋䡚が生 まれるといった状況はみられない。ただし, 今後, 取り組 みを発展させ, 実施対象となる森林の面積が増加していく 中でも, 両自治体が互いのメリットを認識することや，事 業を継続, 発展させていくための首長や担当者レベルの調 整が今後も求められる。

\section{2. 小括}

まず環境譲与税と森林経営管理法の運用では, 市町村の 人的資源の不足が課題として繰り返し指摘されている(今 井 2018 ; 飛田 2019 ; 香坂・内山 2019)。今回, ボトルネッ クとなっている人的資源の制約に対し, 埼玉県から秩父市 への出向職員による運営, 地域抢こし協力隊, 技術系職員 の補強などの運営体制の強化については, 比較的多くの市 町村にとっても参考となる可能性が高い。他地域に扔いて も，国-県，県-市町村への人的交流による「入れ子式」の 運営体制が害施されている（例えば徳島県-那賀町におい ても環境譲与税の使途の担当者が相互に交流)。連携市町 村間で予算を拠出して, 地域として体制を補強する方策に ついては模索されている段階にあるが, 急速に進む少子高 齢化の状況下での一つの方向性として今後の動向を注視す る必要がある。今後, 市町村の林政が, 実態としては県レ ベルの人材の出向による補強によって支えられる構図が固 定化するのか，あるいは長期的にはノウハウが伝播してい き, 市町村レベルの職員や地域の人員へと知識が移行し, 林政のボトムアップにつながるのかが注視される。

また, 都市部と農山村地域に扔ける新たな可能性も示唆 された。環境譲与税をめぐっては, 自治体の人口が配分額 の算定において 3 割影響することから, 都市部の区や市に も相当額の襄与がなされることから, その使途についても 継続的な検討が求められる。都市部における木材利用等の 
需要の喚起を通した吸収源対策も重要であるが, 秩父市と 豊島区の協定のような農山村との提携を推進することを通 し，都市部の環境譲与税を原資とした直接的な森林管理が 広がっていく可能性が本稿の事例を通じて示された。今回 はあくまで，秩父市の市有林での実施だが，今後は経営管 理権を市が取得した私有林での実施の可能性もインタ ビュー時に指摘されている。

さらに都市部の住民が参画する対象事業に対しては，一 過性のイベントとならないように，公共交通機関でアクセ スが可能である場所であること，トイレなどの施設に関す る要望が出ている。トイレなどの施設の要望の高さは，企 業の森づくりでも同様の指摘がなされている（香坂 ら 2015)。

以上，本稿では環境譲与税を活用した今後の都市一農山 村の連携に関する萌芽を提示した。秩父市には豊島区との 1983 年からの姉妹都市としての交流の蓄積，あるいは近 隣の 4 町と連携した協議会などの既存の組織的な枠組みが 存在した。今回の連携事業の実施については, 環境譲与税 の導入のみならず，そのような従前の長期的な取り組みも 基礎となっている点も付記しておく。今後の課題としては, 本連携事業の展開を注視するとともに，連携事業の展開に おける主な要素としての首長の役割やその影響の，詳細な 分析を行う必要があると考えられる。

\section{謝辞}

本研究での調査分析の遂行において多大なるご協力をいただいた, 埼玉県農林部森づくり課, 埼玉県秩父市環境部森づくり課, 東京都 豊島区環境清掃部環境政策課の関係者の皆様にこの場を借りて感謝 の意を表します。

\section{注記}

（注 1） 職員の人件費については，既存の職員の人件費に振替えるこ とは趣旨にそぐわないとされている。ただし，非常勤を含む人 員の補填，体制の補強には支弁可能となっている。

(注 2) 対象自治体へ配分される環境譲与税額総額およびその主な
使途の内訳は次の通りである。尚いずれも 2019 年度の配分額で ある。豊島区：11,240 千円，使途：秩父市との連携事業，基金 積み立て (積立金により豊島区の施設の木質化等を今後予定)。 秩父市：27,208千円，使途：意向調査のための集約化分科会拠 出金, 集約化した私有林の測量 - 資源調査業務委託, 同私有林 の森林整備業務委託, 地域抏こし協力隊による市有林整備のた めの自伐型林業機械購入，としまの森等での上下流交流等。

\section{引用文献}

天田 泰・宮林茂幸・関岡東生（1999）地域開発と「連携」に関す 万一考察，林業経済研究 45(1): 133-138

青山彰久（2015）都市にとっての農村，農村にとっての都市．農村 計画学会誌 34(1): 23-28

秩父市 (2018) 秩父市森林整備計画（平成 30 年 3 月 30 日）

今井 照 (2018) 結局, 自治体はどうすればいいか。（自治体森林政 策の可能性一国税森林環境税・森林経営管理法を手がかりに一. 自治総研ブックレット 22. 飛田博史編, 公人の友社 ). 102-105

梶本尚子・丹治三則・齊藤 修・盛岡 通 (2006) 流域圈における 都市-農村連携型の農村地域将来シナリオ研究. 環境システム研 究論文集 34: 545-551

香坂 玲 · 内山愉太 (2019) 森林環境䜇与税の導入と都道府県への 影響の分析 : 37 府県の概況について。 日林誌 101: 246-252

香坂 玲・戸越祥太・冨吉満之・岩田まり・藤平祥孝・松岡 光 $(2015$ 都市圈以外の地域における中小企業による森づくり活動の定量 的把握：郵送アンケートによる石川県加賀と能登の地域比較よ り。林業経済研究 61 (2) : 13-22

小山 環・十代田朗・津々見崇（2017）都市と農村の交流に関する 言説の変遷．都市計画論文集 $52(2)$ : 198-208

日刊木材新聞 (2019)「推進室が森林環境譲与税対応 現況調査と境 界確認に活用」 2019 年 4 月 6 日 5 面

日刊木材新聞（2019）「未管理の森林整備進める：経営管理権集積計 画を公告：埼玉県秩父市」 2019 年 7 月 18 日， 4 面

農林水産省（2016）2015 年農林業センサス, 第 1 巻 都道府県別統計書

大貝 彰・谷 武 (2010) 自治体連携による住民移動コストから みた基礎的生活サービス拠点配置の分析. 日本建築学会計画系 論文集 75(649): 641-650

林野庁（2017）森林資源の現況（平成 29 年 3 月 31 日）

齋藤朱未（2014）都市農村交流に関する研究動向と今後の展開．農 村計画学会誌 33(3)：343-348

飛田博史 (2019) 国税森林環境税・譲与税創設の経緯とその問題点 自治総研 487: 1-49

豊島区（2019）豊島区環境基本計画（2019-2030）。豊島区環境清掃 部環境政策課

吉弘憲介（2019）森林環境譲与税の譲与基準の試算及びその検討に ついて. 自治総研 484: 3-20 